\title{
An Analysis of the Communication Strategies Employed by Learners of English as a Foreign Language
}

\author{
Montserrat Iglesias Xamaní
}

\author{
Escola Universitària d'Hoteleria i Turisme CETT-UB, University of Barcelona, Barcelona, 08035, Spain \\ *Corresponding Author: montserrat.iglesias@cett.es
}

Copyright (C) 2013 Horizon Research Publishing All rights reserved.

\begin{abstract}
Effective communication skills are most searched for by employers within the tourism industry. Therefore, the ways of developing them are a key issue for researchers, communication instructors and Foreign Language (FL) teachers. This research took place at a School of Tourism and Hospitality Management in Barcelona (Spain). The main purpose consisted in examining the evolution of the participants' oral communicative competence in English as a Foreign Language (EFL), enrolled in a 60-hour English course using learning portfolios. Samples of the learners' speech were gathered at the beginning and at the end of the academic period, and analyzed focusing on fluency, self-confidence and creativity as indicators of progress. The utilization of communication strategies (CSs) in the learners' oral production, conceptually grounded on the guidelines provided by the Common European Framework of Reference for Languages (CEFR), was one of the main objects of the study. The results show that globally the learners' fluency, self-confidence and creativity increased, and eventually most of them used more communicative strategies than at the beginning of the term.
\end{abstract}

Keywords Oral Competence, EFL, Communication Strategies, Portfolio

\section{Introduction}

Communicative competence in English is a must for individuals who wish to study, work and live in today's globalised world, where English is lingua franca. It is a primary objective for learners in higher education settings with international projection willing to start their careers in multicultural contexts. This is certainly the case of those students who are training to hold future middle and top management positions in the tourism industry. Oral communication is particularly important in that sector, and any educational program looking for successful transfer of knowledge should address the question of how to promote the development of oral skills so that the tourism students of today can deal with customers, guests, providers and colleagues efficiently tomorrow. In other words, oral communicative competence in English is a basic need for them, and teachers of English as a Foreign Language (EFL) endeavor to meet such a need in non-English-speaking countries.

The study presented in this article aimed at exploring the impact of portfolios on the development of tourism students' oral communicative competence in English as a Foreign Language. The research was grounded on the theoretical basis provided by the Common European Framework of Reference for Languages (CEFR)[1]. This document, published by the Council of Europe, provides a common basis for language instruction and has been nowadays adopted by the vast majority of higher education institutions, especially in Europe. According to the CEFR "competences are the sum of knowledge, skills and characteristics that allow a person to perform actions. (...) Communicative language competences are those which empower a person to act using specifically linguistic means." (Common European Framework of Reference for Languages: Learning, Teaching, Assessment, 2001, 9).

Following the CEFR, communicative competence is composed of linguistic competences -including lexical, grammatical and phonological knowledge and skills-, sociolinguistic competences -concerning the socio cultural conditions of language use- and pragmatic competences -related to the functional use of linguistic resources. Communicative resources are needed in order to carry out both written and oral communicative activities such as message production and reception, interaction and mediation (i.e. the use of limited linguistic resources to process information and handle meaning equivalences). Thus, language users turn to communication strategies (CSs) to plan, execute, assess and repair their utterances.

Dörnyei \& Scott[2] maintain that the interest in researching CSs originated from the fact that "the mismatch between L2 speakers' linguistic resources and communicative intentions leads to a number of systematic language phenomena whose main function is to handle difficulties or breakdowns in communication" (Dörnyei \& 
Scott, 1997, 174). Generally speaking, CSs can be considered as systematic, communication-enhancing devices used to remedy failure in achieving communicative goals, handle communication difficulties and avoid communication breakdown[3-6].

The notion of CSs in EFL was used by Selinker[7] for the first time, and Savignon[8] introduced pedagogical research focusing on student training in CSs. Varadi[9] expanded on the ideas of Selinker[7] by initiating a systematic analysis of CSs and presenting several taxonomies and terms. CSs and their effect on language acquisition were widely examined in the 1980s and 1990s by a good number of researchers, such as Tarone[10,11] or Bialystok[12-14].

Although several definitions have been offered for second language (L2) CSs[2,6,15-19], the wide range of strategies involved has been an obstacle for reaching a consensus[5], and different definitions have focused on different aspects. Some emphasize the interaction process in communication[20-22], but others consider the behaviors of problem-solving arising from gaps in speakers' linguistic knowledge[19-23]. In some studies[9,13,14,17,24,25] CSs are seen as problem-solving devices that are related to different aspects: problematicity, when the language user recognizes a communication problem; consciousness, when the user is aware of the problem and is consciously utilizing a strategy to resolve it; and intentionality, which implies that the user has the ability to choose between several options for overcoming a communication problem.

As different types of definitions evolved, they led to many different categories of CSs. Dörnyei \& Scott[2] offered a comprehensive review of the various definitions and taxonomies. Most of the existing taxonomies distinguish several types of CSs[17,18], and some of them propose multiple levels of subcategorization[17,26]. The taxonomies of CSs have been based on criteria such as whether language users consult sources of information in their first language (L1) or in their L2, or whether they choose to achieve or reduce the communication goal. Achievement or compensatory strategies are supposed to be used by good language learners[6], while low ability learners are commonly considered to resort to reduction or avoidance strategies[2,6,14,18,19]. Another classification distinguishing between risk-taking strategies and risk-avoidance strategies is based on the framework of Corder[27].

The study presented in this article is grounded on the conceptualization of CSs provided by the CEFR, which considers them lines of action aiming at maximizing communication effectiveness. Following the CEFR, "strategies are a means the language user exploits to mobilize and balance his or her resources, to activate skills and procedures, in order to fulfil the demands of communication in context and successfully complete the task in question in the most comprehensive or most economical way feasible depending on his or her precise purpose. CSs should therefore not be viewed simply with a disability model -as a way of making up for a language deficit or a miscommunication." (Common European Framework of Reference for Languages: Learning, Teaching, Assessment, 2001, 57).

The issue of CSs instruction has always been controversial. According to Canale \& Swain[15] training L2 learners to use CSs in formal learning environments is not essential as they are bound to acquire them in real communication contexts anyway. Paribakht[26] also opposes to specific strategic training and suggests that the successful use of strategies depends upon the availability of other knowledge areas such as contextual, world, and paralinguistic knowledge. Bongaerts \& Poulisse[28] argue that that if the CSs are universal among languages, then learners can readily transfer these strategies from L1 to L2 and there is no need for teaching them either.

On the other hand, a number of researchers[5,19,29-32] have argued in favor of including CSs in language teaching courses. Willems[30] states that since language learners have to be prepared for real-life communicative contexts and they do not always have the required resources at their disposal, it is very important to teach them a set of strategies to overcome communication problems in two ways: they should be made aware of the wide variety of CSs available and they should also practice them so that the utilization of CSs becomes automatic. Brooks[29] points out that learners with a poor knowledge of L2 who carry out communicative activities in a classroom context need to be explicitly taught CSs that they can turn to for successful communication in real-life environments. Dörnyei[5] studied the effective teachability of three types of CSs: topic avoidance and replacement, circumlocution, and using fillers and hesitation devices. Lam \& Wong[32] highlight the relevance that peer assistance and cooperation may have in alleviating the ineffective use of CSs caused by low language ability. Lam[31] examined the impact of explicit metacognitive strategic training and concluded that it had a positive impact on raising the awareness of the learners in terms of the range of CSs they could use. Lam's study[31] confirms the results of a research conducted by Nakatani[19] on the value of awareness raising on strategy use in oral communication.

However, the effectiveness of teaching CSs has not been totally established yet and requires further investigation. The use of CSs can be influenced by a number of factors, such as language proficiency, among many others. Canale \& Swain[15] consider that training in CSs does not have the same relevance for L2 learners of different proficiency levels. They argue that "knowledge of how to use such strategies may be particularly helpful at the beginning stages of second language learning, and it is to be expected that the need for certain strategies may change as a function of age and second language proficiency" (Canale \& Swain, 1980, 31). According to Paribakht[26] learners who are not very proficient rely more on their knowledge of L1, turn to such strategies as idiomatic transfer, and as their proficiency improves they resort more to L2-based strategies. Ellis[33] in turn points out that the CSs used by L2 learners may be characteristic of the stage of development which they have 
reached.

Dörnyei [5] refuses the notion that language proficiency and the use of CSs are significantly related, and is in favor of introducing strategy training at low levels. A study conducted by Bialystok[12] showed that advanced learners used significantly more L2-based strategies such as semantic contiguity while the lower-level students mostly employed L1-based strategies such as language switch. Nevertheless, there was no evidence of a clear relationship between the level of language proficiency and the frequency of the CSs. To sum up, such relationship is another aspect that needs to be researched in more depth, particularly with respect to the development of EFL learners' oral competences.

Let us turn our attention now to the specific features of oral communication. The oral language is a natural code which does not follow the artificial rules of the written language and has some idiosyncratic phonological, lexical, syntactic and text organization features[34,35]. It would not exist without the pronunciation of sounds, bearing in mind that such sounds are not connected in a lineal way, but they are rather structured in groups according to a hierarchy in relation to supra segmental features -the intonation, stress and rhythm of speech. This must be taken into account in language pedagogy.

One of the factors that may interfere with the development of learners' oral skills is reading and writing mediation, or in other words, using the written language in oral situations[36]. Another relevant aspect in foreign language acquisition is pragmatic fluency, defined by House[37] as a "dialogic phenomenon that combines both pragmatic appropriateness of utterances and smooth continuity in ongoing talk" (House, 1996, 228). As a matter of fact, one of the main aims when working on the learners' pronunciation should be the comfortable intelligibility of their speech to enable efficient communication[38]: it is not just a question of pronouncing sounds accurately, but also being able to grasp the speakers' intentions. Hence the importance of paying enough attention to supra segmental features on the one hand and building up the learners' self-confidence as FL speakers on the other hand, since excessive pausing and self-correction may turn them into less fluent -and therefore less communicativelanguage users.

All in all, it seems that alternative methodological tools based on the above mentioned conceptions are in demand for serving the purpose of helping language learners to develop their oral communication skills. This may be the case of learning portfolios.

Delett, Barnhardt \& Kevorkian[39] consider that "portfolios provide a portrait of what students know and what they can do, offer a multidimensional perspective of student progress over time, encourage self-reflection and participation, and link instruction and assessment." (Delett, Barnhardt \& Kevorkian, 2001, 559).

According to Colén, Giné \& Imbernón[40] portfolios can play a significant role in teaching-learning-assessment processes, which should be active, constructive, cumulative and dynamic. These processes can be continuous, multidimensional, context-oriented in order to enable applicability in professional environments, cooperative and prioritizing the provision of feedback.

Language portfolios can promote active learning and self-assessment and the reporting of the development of the students' communicative competence through the provision of students' work samples and with the support of authentic documents. Nevertheless, they must be distinguished from the European Language Portfolio, related to the CEFR as a pedagogical language learning tool which consists of three sections - the language passport, the language biography and the dossier[41].

So far, the focus of portfolio-based language pedagogy has been mainly centered in writing skills[42-49]. Hamp-Lyons \& Condon[50] refer to the main features that typify a model portfolio. To start with, it must judge more than a single performance and its contents must show different areas of expertise by including written productions in several genres.

Hamp-Lyons \& Condon[50] maintain that students must be able to revise their work and participate in the selection process, as they are responsible for their success and should self assess and/or reflect on their learning. Assessment is thus contextualized and evaluators must be able to assess the learners' growth along specific parameters by tracing the development of each artifact.

Current research nowadays tends to delve into electronic portfolios[51]. However, literature on using portfolios especially oriented towards the development of oral skills has been scarce comparatively, so this area remains somewhat unexplored. The need to search for alternative EFL teaching-learning-assessment methods focusing on oral communication originated the study which is presented next.

\section{Materials and Methods}

An action was planned and put into practice for a period of four months with the participation of two groups of $18 \mathrm{EFL}$ students of a Degree in Tourism at Escola Universitària d'Hoteleria i Turisme CETT-UB (EUHT CETT-UB), a School of Tourism and Hospitality Management from the University of Barcelona offering vocational and higher education programs in Barcelona (Spain). The participants' level of English was B1>B2 (following the CEFR) and their 60-hour English course was tourism oriented. They were required to elaborate a portfolio including different types of evidence related to diagnostic tasks, projects, writings, oral presentations, pronunciation activities and other oral production tasks. The main pedagogic objectives consisted in setting out a competence-oriented teaching-learning-assessment approach, designing and undertaking a wide variety of oral tasks and carrying out complementary oral assessment procedures. Throughout the academic period the students engaged in awareness-raising portfolio-related activities and were specifically trained to use a wide range of communication resources. For example, 
they carried out oral presentations on several topics followed by class discussions regarding their communicative effectiveness and the strategies they employed. Besides, they also received feedback from their classmates and the teacher-researcher concerning their strengths and weaknesses, and had to comment on their own performance. This metacognitive tasks derived into portfolio artifacts providing learning evidence.

In order to analyze the progress of the learners' oral skills, they had to produce a recording of a 3-minute monologue at the beginning of the term. An outline could be used as a springboard for their speeches, but they were specifically told not to read a script, as the purpose was producing a sample of relatively spontaneous discourse minimizing reading and writing mediation. In accordance with the instructions they received from the teacher-researcher, they could introduce themselves, explain their course expectations and talk about their previous experience as language learners or about any other topic of their choice. They were free to use any kind of support for their recordings, although digital filing was preferred. The task preparation as well as the recording process were to be carried entirely by themselves as part of their homework.

At the end of the term the students were to incorporate another 5-minute recording in their portfolios following similar guidelines. These pieces of learning evidence were integrated in their curriculum while also being a source of useful research data which offered some indication of the evolution of the learners' communicative competence.

A grid was designed for data collection (see the appendix) based on three selected assessment criteria and taking into account some communicative strategies set by the CEFR: the production strategies needed in discourse planning, execution and repair. Such strategies involve "mobilizing resources, balancing between different competences -exploiting strengths and underplaying weaknesses- in order to match the available potential to the nature of the task." (Common European Framework of Reference for Languages: Learning, Teaching, Assessment, 2001, 63). To be more specific, the main focus was on the ones used in the students' monological speeches for task and message adjustment (specially achievement and avoidance strategies), compensating their weaknesses (including approximating and over generalizing with simpler language, "foreignizing" first language expressions, paraphrasing and describing aspects of what speakers wanted to say), building on previous knowledge, trying out their limited resources and self-correction. Table 1 shows the categorization of the strategies analyzed in the students' speeches following the adapted guidelines of the CEFR.

Table 1. Production strategies

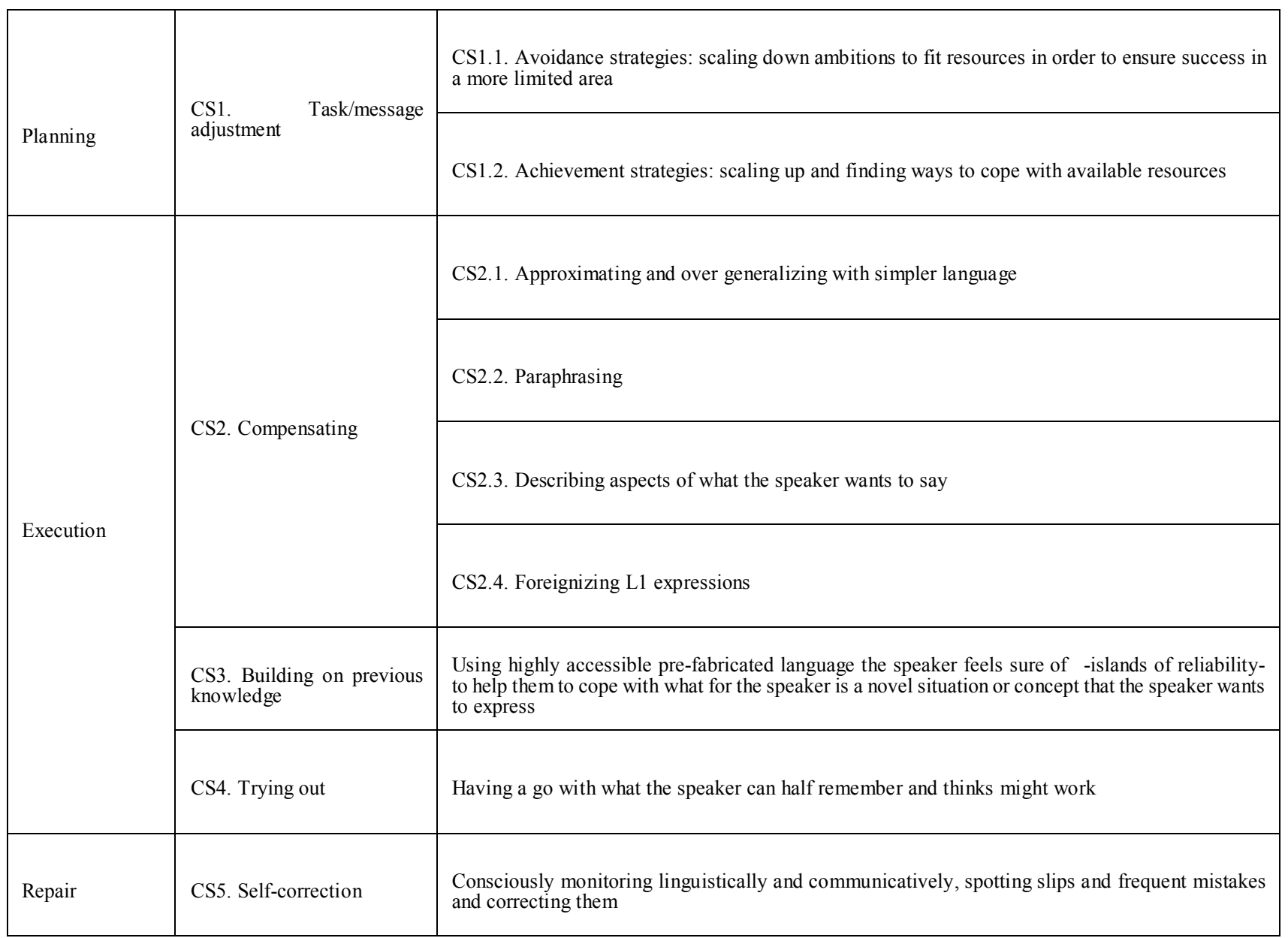


As for the three assessment criteria which indicated discourse adequacy on a scale rating from 1 to 6 , they consisted of fluency, self-confidence and creativity -both in terms of spontaneity and concerning the use of a variety of communicative strategies. The descriptors for each one of these criteria are illustrated in Table 2, Table 3 and Table 4.

Table 2. Descriptors of fluency

\begin{tabular}{|c|c|}
\hline Grade & Descriptor \\
\hline 1 & $\begin{array}{l}\text { The speaker's speech features many hesitations and } \\
\text { pauses }\end{array}$ \\
\hline 2 & The speaker is quite hesitant \\
\hline 3 & $\begin{array}{c}\text { The speaker's speech is slightly fluent, with very } \\
\text { noticeable pausing }\end{array}$ \\
\hline 4 & The speaker is moderately fluent \\
\hline 5 & The speaker's speech is quite fluent, with little hesitations \\
\hline 6 & The speaker is very fluent \\
\hline
\end{tabular}

Table 3 . Descriptors of self-confidence

\begin{tabular}{|c|c|}
\hline Grade & Descriptor \\
\hline 1 & $\begin{array}{c}\text { The speaker does not seem self-confident and does not let } \\
\text { go }\end{array}$ \\
\hline 2 & The speaker sounds quite stiff, but seems to let go a little \\
\hline 3 & The speaker seems moderately inhibited \\
\hline 4 & The speaker looks fairly relaxed \\
\hline 5 & The speaker gives the impression to be rather at ease \\
\hline 6 & The speaker appears to be very self-confident \\
\hline
\end{tabular}

Table 4. Descriptors of creativity

\begin{tabular}{|c|c|}
\hline Grade & \multicolumn{1}{c|}{ Descriptor } \\
\hline 1 & $\begin{array}{r}\text { Very poor and/or short task. The speech follows a } \\
\text { predetermined script closely, with almost no } \\
\text { improvisation and scarce communication strategies }\end{array}$ \\
\hline 2 & $\begin{array}{r}\text { Basic task. The speech clearly follows a script and there } \\
\text { is little improvisation, but it is not entirely } \\
\text { pre-established }\end{array}$ \\
\hline 3 & $\begin{array}{r}\text { The speech follows a script, but it is slightly natural and } \\
\text { dynamic, with some indicators of spontaneity }\end{array}$ \\
\hline 4 & $\begin{array}{r}\text { The speech is based on a script, but it is moderately } \\
\text { spontaneous. The speaker takes reasonable risks }\end{array}$ \\
\hline 5 & $\begin{array}{r}\text { Rich task. The speech is considerably spontaneous and } \\
\text { natural, based on predetermined topics } \\
\text { risks and uses a wide range of communication strategies }\end{array}$ \\
\hline
\end{tabular}

Discourse analysis was carried out to search for indicators in the students' utterances such as linkers, minimizers, prosodic features and paraverbal elements, among other markers. The guidelines provided by Calsamiglia \& Tusón [34] as well as by the CEFR were taken as a reference.
Data were processed by means of descriptive statistics and the results were analyzed qualitatively. After leaving aside the recordings which had not been delivered within the submission deadlines and those which could not be heard due to technical problems, the speeches of 23 participants were analyzed. However, when processing them reading and writing mediation was evident in the monologues of 5 students. For this reason, they were handled separately from the main data corpus.

The following questions were formulated:

1. Was there any evidence of evolution in the learners' final speeches with respect to their initial oral productions?

2. Was there any evidence of progression in the learners' recordings affected by reading and writing mediation?

\section{Results}

The data analysis made it possible to state that globally the students progressed favorably, and the development of their communicative competence was a very positive fact. Generally speaking, fluency, self-confidence and creativity increased in the students' final recordings, and most of them used more communicative resources than at the beginning of the term as evidenced in the appendix, even though there were no major changes in the choice of communicative strategies. Table 5 shows the initial and final mean values referring to fluency, self-confidence and creativity in the main data corpus, as well as the increment experienced both in terms of absolute values and percentages, and also the standard deviations (absolute values could range from 0 to $6)$.

Nevertheless, the evolution shown in the main data corpus differed from the one experienced by the students who read their scripts. In the first case, the most outstanding progression was particularly noticeable in terms of self-confidence and to a lesser extent in relation to creativity and fluency, whereas the monologues with reading and writing mediation were far more creative at the end of the term, since they were more spontaneous than at the beginning, as illustrated in Table 6 .

With respect to the communication strategies employed by the participants, the use of avoidance strategies and achievement strategies was an indicator of how their communicative competence developed. In the main data corpus the achievement strategies clearly outweighed the avoidance strategies in general, both at the beginning and at the end of the academic period. This was not the tendency of the students affected by reading and writing mediation, since all of them resorted to avoidance strategies in their initial speeches. Yet, only $40 \%$ of these students used avoidance strategies in their final recordings and, in addition, $80 \%$ of them incorporated achievement strategies in their final monologues.

In the main data corpus, the most used execution strategy was building on previous knowledge, whereas very few students described aspects of what they wanted to say. In contrast with the initial recordings, some strategies like trying out, self-correction, paraphrasing, approximating and 
over generalizing with simpler language were more abundant in the final speeches, but "foreignizing" first language expressions was a less common practice at the end of the term than at the beginning. Table 7 shows the use of communication strategies in the main data corpus in terms of recurrence and users, i.e. how many times each strategy was used and the percentage of learners who used them.
On the other hand, as indicated in Table 8 all the students who read their scripts "foreignized" first language expressions, built on previous knowledge and tried out their resources in all their monologues, but nobody described aspects of what they wanted to say. This seemed to be the strategy least employed by the participants.

Table 5. Initial and final values of fluency, self-confidence and creativity in the main data corpus

\begin{tabular}{cccc}
\hline & Fluency & Self-confidence & Creativity \\
\hline Initial mean values & 3.4 & 3.1 & 2.7 \\
Final mean values & 4.2 & 4.3 & 3.7 \\
Increment (absolute values) & 0.8 & 1.3 & 1.0 \\
Increment (percentages) & $22.6 \%$ & $41.8 \%$ & $36.7 \%$ \\
Initial standard deviation & 1.57 & 1.68 & 1.41 \\
Final standard deviation & 1.31 & 1.11 & 1.48 \\
\hline
\end{tabular}

Table 6. Initial and final values of fluency, self-confidence and creativity in the data corpus with reading and writing mediation

\begin{tabular}{cccc}
\hline & Fluency & Self-confidence & Creativity \\
\hline Initial mean values & 3.8 & 2.6 & 1.0 \\
Final mean values & 4.0 & 3.2 & 3.0 \\
Increment (absolute values) & 0.2 & 0.6 & 2.0 \\
Increment (percentages) & $5.3 \%$ & $23.1 \%$ & $200.0 \%$ \\
Initial standard deviation & 0.98 & 1.50 & 0.00 \\
Final standard deviation & 0.89 & 0.40 & 1.10 \\
\hline
\end{tabular}

Table 7. Use of communication strategies in the main data corpus

\begin{tabular}{ccccc}
\hline & \multicolumn{2}{c}{ Initial speeches } & \multicolumn{2}{c}{ Final speeches } \\
\hline & Recurrence & Users & Recurrence & Users \\
\hline Building on previous knowledge & 18 & $100 \%$ & 18 & $100 \%$ \\
Achievement strategies & 18 & $100 \%$ & 17 & $94 \%$ \\
Trying out & 17 & $94 \%$ & 18 & $100 \%$ \\
"Foreignizing" first language expressions & 16 & $89 \%$ & 14 & $78 \%$ \\
Approximating/over generalizing & 8 & $44 \%$ & 11 & $61 \%$ \\
Self-correction & 6 & $33 \%$ & 13 & $72 \%$ \\
Avoidance strategies & 2 & $11 \%$ & 1 & $6 \%$ \\
Paraphrasing & 2 & $11 \%$ & 5 & $28 \%$ \\
\hline Describing aspects of what wants to be said & 0 & $0 \%$ & 2 & $11 \%$ \\
\hline
\end{tabular}

Table 8. Use of communication strategies in the data corpus with reading and writing mediation 


\begin{tabular}{ccccc}
\hline & \multicolumn{2}{c}{ Initial speeches } & \multicolumn{2}{c}{ Final speeches } \\
\hline & Recurrence & Users & Recurrence & Users \\
\hline Building on previous knowledge & 5 & $100 \%$ & 5 & $100 \%$ \\
Trying out & 5 & $100 \%$ & 5 & $100 \%$ \\
"Foreignizing" first language expressions & 5 & $100 \%$ & 5 & $100 \%$ \\
Avoidance strategies & 5 & $100 \%$ & 2 & $40 \%$ \\
Approximating/over generalizing & 2 & $40 \%$ & 2 & $40 \%$ \\
Self-correction & 1 & $20 \%$ & 4 & $80 \%$ \\
Achievement strategies & 0 & $0 \%$ & 4 & $80 \%$ \\
Paraphrasing & 0 & $0 \%$ & 2 & $40 \%$ \\
Describing aspects of what wants to be said & 0 & $0 \%$ & 0 & $0 \%$ \\
\hline
\end{tabular}

\section{Discussion}

On the whole, improvement was more remarkable in the utterances of the learners whose level of English was lower at the beginning of the term. This was very clear as far as self-confidence was concerned, and those students who were very self-confident initially mostly remained the same -or exceptionally became less self-confident- at the end of the term. To a certain extent, in the main data corpus fluency followed a similar pattern, while the starting point was not a determining factor concerning creativity.

The general evolution experienced by the learners in such a short period of time must be highlighted, especially in the case of those who had a higher initial level. Progress in lower levels is usually easier to achieve, while the students with a certain level of communicative competence tend to come to a standstill and it is more difficult for them to perceive that they are improving.

As for the recordings of those students who read their speeches at the beginning of the term, checking the progress of their fluency and self-confidence was an interesting issue. Reading a script literally may help learners to be more self-confident and fluent, even though their naturalness and expressiveness may be affected negatively. Therefore, letting go of the written text should be seen as a step forward, and showing a similar level of fluency in more improvised speeches at the end of the term must be considered positive. All in all, the effort made by those students ought to be valued and the fact that very inhibited learners became more self-confident despite not having a written text to support them was an accomplishment.

In terms of communication strategies, the increase of achievement strategies over avoidance strategies is clearly an advance. The fact that the most recurrent strategies were building on previous knowledge, trying out and "foreignizing" first language expressions might mean that these strategies are easier to resort to, while describing aspects of what wants to be said seems far more demanding for students. Now, are some of these strategies better than the rest? Which strategies have to be promoted? Which ones are not recommendable?

The CEFR supports the development of strategies that will enable users to perform tasks as "the objective is to improve the strategies traditionally used by the learner by rendering them more sophisticated, more extensive and more conscious, by seeking to adapt them to tasks for which they had not originally been used. Whether these are communication or learning strategies, if one takes the view that they enable an individual to mobilise his or her own competences in order to implement and possibly improve or extend them, it is worthwhile ensuring that such strategies are indeed cultivated as an objective." (Common European Framework of Reference for Languages: Learning, Teaching, Assessment, 2001, 137). Learners should therefore be trained to use a wide range of strategies, and offering them several opportunities for strategic practice accompanied by feedback provision throughout the academic period ought to contribute to raise their awareness. This key aspect needs to be incorporated in EFL learning curricula focusing on communicative competence.

An important issue that should be considered at this point is how communication strategies are built up in the EFL classroom. Some of these strategies, such as "foreignizing" L1 expressions, trying out, approximating or over generalizing, are sometimes penalized systematically by teachers who are mostly concerned with accuracy and would probably prefer to avoid them. However, they must be viewed as indicators of progress and at certain interlanguage stages they should be encouraged. Resorting to remedial resources to compensate language deficiency is definitely more advisable than no communication at all. In that sense, in reply to the question of which strategies ought to be taught and which ones should be left aside any strategy, including avoidance ones, can be useful and may play a significant communicative role, particularly at low proficiency levels. Nevertheless, learners should be instructed not to stick to the same limited resources by incorporating more achievement strategies and improving both their fluency and their accuracy as language users as they become more proficient. If transferability from educational contexts to professional 
real-life environments is searched for, this is particularly true in the case of those learners who will need to employ more sophisticated language tools to function in the service sector, where quality of service is a must.

However, in the learning process students should be ready to take risks and make mistakes so that they can learn from them. Positive feedback ought to aim at going beyond accuracy shortages in search of progress. Yet, when it comes to assessing learners' performance the dilemma of how to rate efficient communication is not easily faced. Teachers ought to keep in mind the idiosyncrasy of oral language. Hesitations, inaccuracy and self-correction are present in first language daily use, so why do teachers sometimes disdain these features? Especially if the target is not native-like English, but rather comfortable intelligibility to enable efficient communication in English, or, some may argue, in the language of tomorrow: Globish. Efficient non-native English speakers turn to all sorts of resources in the real world, both in personal and professional contexts. Again, if higher education institutions are to guarantee the transfer of knowledge and enable university students to become successful professionals and citizens this reality cannot be overlooked.

The key to efficiency lies in finding the balance between accurate adequacy and pragmatic fluency. Proactive teachers should have a multidimensional approach and try to make sure that: pronunciation is also worked on at a supra segmental level to minimize communication breakdowns caused by mispronunciation interference; enough attention is paid to communication strategies; mistakes are dealt with constructively; self-correction and peer-correction are fostered under the teacher's supervision; and finally, learners become aware of their strengths and weaknesses through reflection processes.

\section{Conclusion}

Taking into account the time constraints deriving from a 60 -hour course, the results are significant. The limitations were mainly related to workload and time consumption in terms of feedback provision, two relevant factors to take into account when it comes to considering the viability of portfolios in large groups of learners.
It must be pointed out that on the whole the positive results that have been presented led to consider that the work carried out through portfolios helped to develop the oral competences of those students who took part in this project. The research actually had some pedagogical implications in the curriculum design of EFL credits within the Degree in Tourism. The most outstanding outcome consisted in standardizing the use of portfolios as a teaching-learning-assessment tool, since it was widely introduced in all the English courses at EUHT CETT-UB.

To allow for consistency and viability, at present the artifacts included in the learners' portfolios have been restricted to an initial questionnaire, a final questionnaire, a sample of written production and a sample of oral productions, both accompanied with reflection tasks. Teachers are entitled to adapt this tool to their students' needs and to their teaching styles, to make the most of them. After all, due to their flexible nature portfolios can be tailored to different learning and teaching profiles in most fields of study through both analogical and digital support, since this method can cater for any pedagogical need in any educational context. As a matter of fact, future lines of research in applied linguistics might consider exploring the potential of online portfolios, particularly with respect to the development of oral skills, and their ever-changing innovative applicability options.

As for the focus on communication strategies in the English classroom, different tasks are currently set out at EUHT CETT-UB: fluency-oriented activities that encourage risk-taking to express complex ideas regardless of mistakes; accuracy-oriented activities to encourage self-correction; paraphrasing exercises; games that involve description techniques without using specifically "forbidden" key words; recording the learners' speeches for self-repair or for further selective feedback from the teacher and/or classmates; commenting on the students' presentations using grids for peer-correction; teacher supervision through individual tutorials; and last but not least, paying attention to nonverbal resources and body language during oral presentations. All these tasks can be carried out in any language learning program where communication is a high priority. 


\section{Appendix}

Data collection grids $(\mathrm{ST}=\mathrm{Student}$ identification $/ \mathrm{R} 1=$ Initial recording $/ \mathrm{R} 2=$ Final recording)

\begin{tabular}{|c|c|c|}
\hline ST1. R1 & Communication strategies & Indicators \\
\hline Fluency: 3 & Planning: CS1.1 (Reads!) & \multirow{3}{*}{$\begin{array}{l}\text {-Self-correction: "persons", "near of my house" } \\
\text {-Islands of reliability: personal introduction } \\
\text {-Foreignizing/trying out: " "I have } 19 \text { years", "I have born" }\end{array}$} \\
\hline Self-confidence: 1 & $\begin{array}{l}\text { Execution: } \\
\text { /CS3/CS4 }\end{array}$ & \\
\hline Creativity: 1 & Repair: CS5 & \\
\hline ST1. R2 & Communication strategies & Indicators \\
\hline Fluency: 4 & Planning: CS1.2 & \multirow{3}{*}{$\begin{array}{l}\text {-Self-correction + apology: "sorry!" (politeness strategy) } \\
\text {-Fillers: fixed expressions ("I can say that"), vocalizations (“eh...") } \\
\text {-Modalitzation: "more or less", "really" } \\
\text {-Foreignizing/trying out: "what more?" } \\
\text {-Hints of laughter (1'52", 3'01") } \\
\text {-Repetition: "really, really, really", "I know, I know" }\end{array}$} \\
\hline Self-confidence: 3 & $\begin{array}{l}\text { Execution: } \\
\text { /CS3/CS4 }\end{array}$ & \\
\hline Creativity: 3 & Repair: CS5 & \\
\hline ST2. R1 & Communication strategies & Indicators \\
\hline Fluency: 3 & Planning: CS1.1 (Reads!) & \multirow{3}{*}{$\begin{array}{l}\text {-Islands of reliability: personal intro., reference to previous script } \\
\text {-Foreignizing/trying out: "a hotel propierty of my mother", "since I } \\
\text { have } 5 \text { years old", "more facilities and more fluency", "I am not } \\
\text { prepared for do it" }\end{array}$} \\
\hline Self-confidence: 1 & $\begin{array}{l}\text { Execution: } \\
\text { /CS3/CS4 }\end{array}$ & \\
\hline Creativity: 1 & Repair: --- & \\
\hline ST2. R2 & Communication strategies & Indicators \\
\hline Fluency: 3 & Planning: CS1.2 & \multirow{3}{*}{$\begin{array}{l}\text {-Fillers: repetition, stretched vowels, fixed expressions ("of course") } \\
\text {-Islands of reliability: personal introduction, fixed expressions, } \\
\text { reference to script (course objectives) } \\
\text {-Reformulation: "there are some... a lot of activities", "a oral... a } \\
\text { listening part" } \\
\text {-Self-correction: "I like the vocabulary activity... activities", } \\
\text {-Foreignizing/trying out: "interessant", "traduction", "it's more easy", } \\
\text { "pronunciate good" } \\
\text {-Overgen.: "things like that", "that's a good thing", "for the same } \\
\text { thing" } \\
\text {-Modalization: "more or less", "I like so much" } \\
\text {-Expressiveness: intonation ( } 438 \text { "), stress (5'50"), laughter (2'22") }\end{array}$} \\
\hline Self-confidence: 4 & $\begin{array}{l}\text { Execution: CS2.1/CS2.2/ } \\
\mathrm{CS} 2.4 / \mathrm{CS} 3 / \mathrm{CS} 4\end{array}$ & \\
\hline Creativity: 5 & Repair: CS5 & \\
\hline ST3. R1 & Communication strategies & Indicators \\
\hline Fluency: 3 & Planning: CS1.2 & \multirow{3}{*}{$\begin{array}{l}\text {-Foreignizing/trying out: "qualificate", "touristic(al)" } \\
\text {-Fillers: pet words ("well”), vocalizations ("eh...") } \\
\text {-Islands of reliability: fixed expr. ("as a conclusion I could say that") } \\
\text {-Modalization: "maybe" } \\
\text {-Repetition: "for us to, to", "we can find it on, on" }\end{array}$} \\
\hline Self-confidence: 3 & $\begin{array}{l}\text { Execution: } \\
\text { /CS3/CS4 }\end{array}$ & \\
\hline Creativity: 5 & Repair: --- & \\
\hline ST3. R2 & Communication strategies & Indicators \\
\hline Fluency: 4 & Planning: CS1.2 & \multirow{3}{*}{$\begin{array}{l}\text {-Foreignizing: "arriving at this point", "it's going on the first place" } \\
\text {-Fillers: laughter, fixed expressions ("I don't know exactly what to talk } \\
\text { about", "it's ok"), vocalizations ("eh..."), pet words ("well"), repetition } \\
\text { ("like the, like the") } \\
\text {-Self-correction (3'22") } \\
\text {-Paraphrasing (3'31") }\end{array}$} \\
\hline Self-confidence: 4 & $\begin{array}{l}\text { Execution: CS2.2/CS2.3/ } \\
\mathrm{CS} 2.4 / \mathrm{CS} 3 / \mathrm{CS} 4\end{array}$ & \\
\hline Creativity: 5 & Repair: CS5 & \\
\hline ST4. R1 & Communication strategies & Indicators \\
\hline Fluency: 1 & Planning: CS1.2 & \multirow{2}{*}{$\begin{array}{l}\text {-Islands of reliability: personal introduction, explicit reference to } \\
\text { script, fixed expressions ("thank you for your attention") } \\
\text {-Fillers: vocalizations, repetition, pet words ("well”) }\end{array}$} \\
\hline Self-confidence: 1 & $\begin{array}{l}\text { Execution: CS2.1/CS2.2/ } \\
\mathrm{CS} 2.4 / \mathrm{CS} 3 / \mathrm{CS} 4\end{array}$ & \\
\hline
\end{tabular}




\begin{tabular}{|c|c|c|}
\hline Creativity: 2 & Repair: --- & $\begin{array}{l}\text {-Reformulation: "it's very... it can be very silly" } \\
\text {-Foreignizing/trying: "without think", "I expect can be able to speak" } \\
\text {-Overgeneral.: "wherever", "with anybody", "if you need something" } \\
\text {-Use of L1: "soltura", "no sé... I don't know" } \\
\text {-Prosodic features: intonation (1.2.AVI 00'09", 1.3.AVI 00'30") }\end{array}$ \\
\hline ST4. R2 & Communication strategies & Indicators \\
\hline Fluency: 1 & Planning: CS1.2 & \multirow{3}{*}{$\begin{array}{l}\text {-Fillers: vocalizations, stretched vowels, repetition, pet words ("well") } \\
\text {-Foreignizing/trying out: "more fast", "I comit more mistakes", "for } \\
\text { me has been a difficult task" } \\
\text {-Modalization: "I think" } \\
\text {-Expressiveness: intonation (3.AVI 00'17"), laughter (3.AVI 00'30") } \\
\text {-Islands of reliability: introduction } \\
\text {-Self-correction: "the portfolio have been... has been" }\end{array}$} \\
\hline Self-confidence: 3 & $\begin{array}{l}\text { Execution: } \\
\text { /CS3/CS4 }\end{array}$ & \\
\hline Creativity: 1 & Repair: CS5 & \\
\hline ST5. R1 & Communication strategies & Indicators \\
\hline Fluency: 5 & Planning: CS1.2 & \multirow{3}{*}{$\begin{array}{l}\text {-Expressiveness: conviction!! (through intonation and rhythm) } \\
\text {-Islands of reliability: personal introduction, pet words ("obviously"), } \\
\text { fixed expressions ("I have to say"), linkers } \\
\text {-Fillers: paraverbal elements (vocalizations, stretched sounds), } \\
\text { repetition, fixed expressions, pet words } \\
\text {-Foreignizing/trying out: "to go to class in this hour" }\end{array}$} \\
\hline Self-confidence: 5 & $\begin{array}{l}\text { Execution: } \\
\text { /CS3/CS4 }\end{array}$ & \\
\hline Creativity: 4 & Repair: --- & \\
\hline ST5. R2 & Communication strategies & Indicators \\
\hline Fluency: 5 & Planning: CS1.2 & \multirow{3}{*}{$\begin{array}{l}\text {-Islands of reliability: personal introduction, pet words ("well"), fixed } \\
\text { expressions ("in general") } \\
\text {-Fillers: fixed expressions, pet words, repetition, vocalizations } \\
\text {-Overgeneralizing: "is a thing","there are things that I can't reproduce" } \\
\text {-Foreignizing/trying out: "notes" (instead of "marks"), "I did the } \\
\text { portfolio mine", "orals presentations" } \\
\text {-Modalization: "maybe" } \\
\text {-Self-correction: "I go to... I went to","I like doing... I like } \\
\text { do"(wrong!) }\end{array}$} \\
\hline Self-confidence: 6 & $\begin{array}{l}\text { Execution: CS2.1/CS2.4/ } \\
\text { /CS3/CS4 }\end{array}$ & \\
\hline Creativity: 5 & Repair: CS5 & \\
\hline ST6. R1 & Communication strategies & Indicators \\
\hline Fluency: 5 & Planning: CS1.2 & \multirow{3}{*}{$\begin{array}{l}\text {-Fillers: vocalizations, stretched sounds, repetition, fixed expressions } \\
\text {-Islands of reliability: personal introduction, fixed expressions ("that's } \\
\text { all", "thank you", "I don't know") } \\
\text {-Expressiveness: laughter, makes a joke (2'20") } \\
\text {-Modalization: "I think", "probably" } \\
\text {-Approximating: "something like that" } \\
\text {-Self-correction: "fourth level... fourth year", "I use to... I used to" }\end{array}$} \\
\hline Self-confidence: 6 & Execution: CS2.1/CS3/CS4 & \\
\hline Creativity: 5 & Repair: CS5 & \\
\hline ST6. R2 & Communication strategies & Indicators \\
\hline Fluency: 5 & Planning: CS1.2 & \multirow{3}{*}{$\begin{array}{l}\text {-Foreignizing/trying out: "centrate", "exigence", "go another time in } \\
\text { another country" } \\
\text {-Fillers: repetition, vocalizations, stretched vowels, pet words } \\
\text {-Modalization: "probably", "I think", "very, very, very poor" } \\
\text {-Islands of reliability: fixed expressions ("that's all") } \\
\text {-Self-correction: "I have gave you...I will give you", "I will make...I } \\
\text { will do, sorry" (politeness strategy) } \\
\text {-Expressiveness: laughter (3'50") }\end{array}$} \\
\hline Self-confidence: 5 & Execution: CS2.4/CS3/CS4 & \\
\hline Creativity: 5 & Repair: CS5 & \\
\hline ST7. R1 & Communication strategies & Indicators \\
\hline Fluency: 1 & Planning: CS1.1 (Reads!) & \multirow{3}{*}{$\begin{array}{l}\text {-Islands of reliability: formal presentation signposting, follows an } \\
\text { autobiographical script closely } \\
\text {-Foreignizing/trying out: "restauration", "enough hard", "with } 6 \text { years } \\
\text { old", "academy", "during } 2 \text { years", "I began the practice" } \\
\text {-Fillers: Scarce repetition/vocalization ("'mmm"...) towards the end } \\
\text {-Prosodic features: characteristic rhythm/intonation of read }\end{array}$} \\
\hline Self-confidence: 3 & Execution: CS2.4/CS3/CS4 & \\
\hline Creativity: 5 & Repair: CS5 & \\
\hline
\end{tabular}




\begin{tabular}{|c|c|c|}
\hline & & monologues (2'18"), neutral tone \\
\hline ST7. R2 & Communication strategies & Indicators \\
\hline Fluency: 2 & Planning: CS1.1 (Reads!) & \multirow{3}{*}{$\begin{array}{l}\text {-Foreignizing/trying out: "academy", "with } 17 \text { years old", "I have } \\
\text { made the practice" (often similar to R1) } \\
\text {-Fillers: vocalizations, repetition } \\
\text {-Use of L1: "Bella durmiente" } \\
\text {-Islands of reliability: Follows similar script/structure to R1 } \\
\text {-Prosodic features: similar rhythm/intonation/tone to R1 } \\
\text {-Self-correction: "to do... due to" }\end{array}$} \\
\hline Self-confidence: 3 & Execution: CS2.4/CS3/CS4 & \\
\hline Creativity: 5 & Repair: CS5 & \\
\hline ST8. R1 & Communication strategies & Indicators \\
\hline Fluency: 3 & Planning: CS 1.2 & \multirow{3}{*}{$\begin{array}{l}\text {-Foreignizing/trying out: "I better my English", "I expect to can } \\
\text { speak", "I expect to solutionate" } \\
\text {-Islands of reliability: intro., reference to script (course objectives) } \\
\text {-Fillers: vocalizations, repetition, stretched vowels } \\
\text {-Modalization: "I think", "the language are so important" } \\
\text {-Over generalizing: "all these things", "I will know another things" } \\
\text {-Prosodic features: intonation (0'22", } 0 \text { '41") }\end{array}$} \\
\hline Self-confidence: 5 & $\begin{array}{l}\text { Execution: CS2.1/CS2.4/ } \\
\text { /CS3/CS4 }\end{array}$ & \\
\hline Creativity: 5 & Repair: --- & \\
\hline ST8. R2 & Communication strategies & Indicators \\
\hline Fluency: 4 & Planning: CS1.2 & \multirow{3}{*}{$\begin{array}{l}\text {-Over generalizing: "I have learned a lot of things" } \\
\text {-Fillers: vocalizations, repetition, stretched vowels, fixed expressions } \\
\text { ("I can say that") } \\
\text {-Islands of reliability: introduction, reference to script, exemplification } \\
\text {-Self-correction: "this was be... was a good exercise", "I too... me too", } \\
\text { "this exercise had... have helped" (wrong!) } \\
\text {-Reformulation: "my sector... my industry", "one part of this project or } \\
\text { one exercise" } \\
\text {-Foreignizing/trying out: "how I said now", "in the initial of the term" } \\
\text {-Modalization: "I think", "the grammar perhaps is better" }\end{array}$} \\
\hline Self-confidence: 5 & $\begin{array}{l}\text { Execution: CS2.1/CS2.2/ } \\
\text { CS2.4/CS3/CS4 }\end{array}$ & \\
\hline Creativity: 4 & Repair: CS5 & \\
\hline ST9. R1 & Communication strategies & Indicators \\
\hline Fluency: 3 & Planning: CS1.1/CS1.2 & \multirow{3}{*}{$\begin{array}{l}\text {-Islands of reliability: personal intro., reference to script, fixed expr. } \\
\text { ("I have to say that"), enumeration (hobbies, preferences, course } \\
\text { novelties) } \\
\text {-Foreignizing/trying out: "she's nurse", "it's near from the Sagrada } \\
\text { Família", "it's the same than in the first course" } \\
\text {-Modalization: "I think that I will get it" } \\
\text {-Expressiveness: intonation (in enumerations/sentence endings) }\end{array}$} \\
\hline Self-confidence: 3 & Execution: CS2.4/CS3/CS4 & \\
\hline Creativity: 1 & Repair: --- & \\
\hline ST9. R2 & Communication strategies & Indicators \\
\hline Fluency: 5 & Planning: CS1.2 & \multirow{3}{*}{$\begin{array}{l}\text {-Over generalizing: "these things", "more things", "different things" } \\
\text {-Islands of reliability: fixed expressions ("I have to say that"), linkers } \\
\text {-Fillers: fixed expressions, pet words ("well") } \\
\text {-Modalization: "a little bit" } \\
\text {-Improved pronunciation of endings: "tourism", "learned", "travelled" }\end{array}$} \\
\hline Self-confidence: 6 & Execution: CS2.1/CS3/CS4 & \\
\hline Creativity: 3 & Repair: --- & \\
\hline ST10. R1 & Communication strategies & Indicators \\
\hline Fluency: 3 & Planning: CS1.2 & \multirow{3}{*}{$\begin{array}{l}\text {-Self-correction + apology: "I miss... I need, sorry", "exercise... } \\
\text { exercises, sorry" (politeness strategy) } \\
\text {-Islands of reliability: personal introduction, reference to previous } \\
\text { script, linkers, fixed expressions } \\
\text {-Fillers: pet words ("ok?", "well"), fixed expressions, vocalizations, } \\
\text { stretched vowels, repetition, laughter } \\
\text {-Foreignizing/trying out: "tourist career", "gramatic" }\end{array}$} \\
\hline Self-confidence: 3 & Execution: CS2.4/CS3/CS4 & \\
\hline Creativity: 2 & Repair: CS5 & \\
\hline ST10. R2 & Communication strategies & Indicators \\
\hline Fluency: 3 & Planning: CS1.2 & \multirow{2}{*}{$\begin{array}{l}\text {-Self-correction + apology: "I talk with he... with her, sorry", she are... } \\
\text { she were, sorry, she was in Vilanova" (politeness strategy) }\end{array}$} \\
\hline Self-confidence: 3 & Execution: CS.2.1/CS2.4/ & \\
\hline
\end{tabular}




\begin{tabular}{|c|c|c|}
\hline & $\mathrm{CS} 3 / \mathrm{CS} 4$ & \multirow{2}{*}{$\begin{array}{l}\text {-Fillers: rep., vocalizations, stretched vowels, pet words ("well", "ok") } \\
\text {-Over generalizing: "and others", "anothers" (wrong!) } \\
\text {-Islands of reliability: personal introduction, reference to script, linkers } \\
\text {-Foreignizing/trying out: "another career", "a rabbit course", "I would } \\
\text { like that you can compare" }\end{array}$} \\
\hline Creativity: 4 & Repair: CS5 & \\
\hline ST11. R1 & Communication strategies & Indicators \\
\hline Fluency: 3 & Planning: CS1.1 (Reads!) & \multirow{3}{*}{$\begin{array}{l}\text {-Foreignizing/trying out: "the continue evaluation", "I hope the } \\
\text { weathers get better English" } \\
\text {-Islands of reliability: follows a previous script closely } \\
\text {-Over generalizing: "basic things", "I want to improve these topics" } \\
\text {-Prosodic features: intonation (in enumerations), rhythm, word linking } \\
\text {-Fillers: scarce stretched vowels }\end{array}$} \\
\hline Self-confidence: 5 & $\begin{array}{l}\text { Execution: CS.2.1/CS2.4/ } \\
\text { CS3/CS4 }\end{array}$ & \\
\hline Creativity: 1 & Repair: --- & \\
\hline ST11. R2 & Communication strategies & Indicators \\
\hline Fluency: 3 & Planning: CS1.1/CS1.2 & \multirow{3}{*}{$\begin{array}{l}\text {-Foreignizing/trying out: "I want a good note", "I have careful" } \\
\text {-Islands of reliability: personal introduction, reference to script, linkers } \\
\text { ("moreover", "in conclusion") } \\
\text {-Prosodic features: intonation (in enumerations), rhythm, neutral tone } \\
\text {-Fillers: scarce repetition/stretched sounds }\end{array}$} \\
\hline Self-confidence: 3 & Execution: CS2.4/CS3/CS4 & \\
\hline Creativity: 2 & Repair: --- & \\
\hline ST12. R1 & Communica & Indicators \\
\hline Fluency: 3 & Planning: CS1.1/CS1.2 & \multirow{3}{*}{$\begin{array}{l}\text {-Islands of reliability: personal introduction, reference to script, linkers } \\
\text {-Fillers: vocalizations, stretched vowels } \\
\text {-Over generalizing: "other things" } \\
\text {-Foreignizing/trying out: "career", "necessary" (pronunciation), } \\
\text { "arrive to Spain" }\end{array}$} \\
\hline Self-confidence: 1 & $\begin{array}{l}\text { Execution: C } \\
\text { CS3/CS4 }\end{array}$ & \\
\hline Creati & Repair: --- & \\
\hline & & Indicators \\
\hline Fluency: 2 & Plann & \multirow{3}{*}{$\begin{array}{l}\text {-Over generalizing: "all things", "every things", "interactive things" } \\
\text {-Islands of reliability: reference to script, linkers } \\
\text {-Fillers: repetition, vocalizations } \\
\text {-Foreignizing/trying out: "the class of language", "the tourism" } \\
\text {-Expressiveness: more relaxed! (intonation /occasional slow rhythm) }\end{array}$} \\
\hline Self-confidence: 3 & $\begin{array}{l}\text { Execution: CS.2.1/C } \\
\text { CS3/CS4 }\end{array}$ & \\
\hline Creativity: 2 & Repair: --- & \\
\hline ST13. R1 & Commun & Indicators \\
\hline Fluency: 1 & Planning: CS1.2 & \multirow{3}{*}{$\begin{array}{l}\text {-Foreignizing/trying out: "for this motive", "I hope improve", "lost my } \\
\text { shame", "diplomature" } \\
\text {-Islands of reliability: personal introduction, reference to script } \\
\text {-Fillers: cough, vocalizations, constant repetition ("I live, I live in } \\
\text { Barcelona and, and..."), pet words ("well") }\end{array}$} \\
\hline Self-confidence: 1 & Execution: & \\
\hline Creativity: 3 & Repair: --- & \\
\hline ST13. R2 & Communication s & Indicators \\
\hline Fluency: 3 & Planning: CS 1.2 & \multirow{3}{*}{$\begin{array}{l}\text {-Foreignizing/trying out: "it cost me more to speak", "you want } \\
\text { travel", "lose fear", "it is one of the levels where more has worked" } \\
\text {-Fillers: vocalizations, repetition ("I feel, I feel..."), pet words ("well”) } \\
\text {-Islands of reliability: fixed expressions ("in conclusion") } \\
\text {-Modalization: "maybe", "I think", "I believe" }\end{array}$} \\
\hline Self-confidence: 3 & Execution: CS2.4 & \\
\hline Creativity: 3 & Repair: --- & \\
\hline ST14. R1 & Communication strategies & Indicators \\
\hline Fluency: 5 & Planning: CS1.2 & \multirow{3}{*}{$\begin{array}{l}\text {-Foreignizing/trying out: "the unique solution", "I must conform", } \\
\text { "impressionant", "I have a lot of luck", "I can valorate" } \\
\text {-Islands of reliability: personal intro., pet words ("fortunately"), fixed } \\
\text { expressions ("thank you for your attention"), enumeration (countries) } \\
\text {-Fillers: vocalizations ("eh..."), fixed expressions, repetition ("and, and } \\
\text { I know", "the CETT course in Barcelona, in CETT") }\end{array}$} \\
\hline Self-confidence: 5 & Execution: CS2.4/CS3/CS4 & \\
\hline Creativity: 3 & Repair: --- & \\
\hline ST14. R2 & Communication strategies & \multirow{3}{*}{$\begin{array}{l}\text {-Foreignizing/trying out: "how I said before", "I go in Easter to see } \\
\text { her" }\end{array}$} \\
\hline Fluency: 5 & Planning: CS1.2 & \\
\hline Self-confidence: 5 & Execution: CS2.4/CS3/CS4 & \\
\hline
\end{tabular}




\begin{tabular}{|c|c|c|}
\hline Creativity: 5 & Repair: CS5 & $\begin{array}{l}\text {-Fillers: vocalizations, repetition, pet words ("well”) } \\
\text {-Islands of reliability: fixed expressions ("thank you for your attention } \\
\text { and bye, bye") } \\
\text {-Self-correction: "I can... I can't" (emphasizing), "I lost... loss my little } \\
\text { shy" (trying out wrong pronunciation!) }\end{array}$ \\
\hline ST15. R1 & Communication strategies & Indicators \\
\hline Fluency: 3 & Planning: CS1.2 & \multirow{3}{*}{$\begin{array}{l}\text {-Islands of reliability: personal intro., pet words ("you know", "well") } \\
\text {-Fillers: vocalizations ("eh..."), pet words, repetition ("more, more") } \\
\text {-Self-correction: "I can spoke... speak", "then... there come" } \\
\text {-Reformulation: "English is like... English language is a", "at this } \\
\text { moment.... at the present" (trying out wrong reformulation!) }\end{array}$} \\
\hline Self-confidence: 1 & Execution: $\mathrm{C}$ & \\
\hline Creativity: 1 & Repair: & \\
\hline ST15. R2 & Communication strategies & Indicators \\
\hline Fluency: 4 & Planning: CS1.2 & \multirow{3}{*}{$\begin{array}{l}\text {-Self-correction + apology: "I'm always asking... sorry, I'm always } \\
\text { answer this" (politeness strategy) } \\
\text {-Islands of reliability: fixed expressions ("sorry about that", "as I said } \\
\text { before", "see you"), pet words ("well”), abundant exemplification } \\
\text {-Fillers: vocalizations, fixed expressions, pet words, enumerations } \\
\text { (tourist attractions/nationalities), repetition ("hard work, hard work", } \\
\text { "because, because", "23 floor... } 23 \text { floor, yes") }\end{array}$} \\
\hline Self-confidence: 5 & Execution: CS2.3 & \\
\hline Creativity: 4 & Repair: CS5 & \\
\hline ST16. F & Comn & \\
\hline Fluency: 3 & Planning: CS1.2 & \multirow{3}{*}{$\begin{array}{l}\text {-Islands of reliability: personal introduction, explicit reference to } \\
\text { script, fixed expressions ("that's all") } \\
\text {-Approximating: "things like that" } \\
\text {-Over generalizing: "all these things" } \\
\text {-Fillers: vocalizations, pet words ("well"), fixed expressions ("you } \\
\text { know"), stretched vowels } \\
\text {-Prosodic features: intonation (2'20") } \\
\text {-Foreignizing/trying:"I pretend to know","to defend me", "present me" } \\
\text {-Modalization: "it's just numbers", it seems to be quite easy" }\end{array}$} \\
\hline Self-confidence: 3 & $\begin{array}{l}\text { Execution: CS.2.1/CS2.4/ } \\
\text { CS3/CS4 }\end{array}$ & \\
\hline Creativity: 3 & Repair: --- & \\
\hline ST16. R2 & Communication s & \\
\hline Fluency: 5 & Planning: CS1.2 & \multirow{3}{*}{$\begin{array}{l}\text {-Islands of reliability: explicit reference to script, exemplification, } \\
\text { fixed expressions ("I want to say") } \\
\text {-Over generalizing: "a lot of things" } \\
\text {-Modalization: "I'm quite proud", "I think it’s really important" } \\
\text {-Fillers: pet words ("well"), fixed expressions, repetition, scarce } \\
\text { stretched sounds } \\
\text {-Prosodic features: intonation ( ( } 0^{\prime} 09 \text { ") } \\
\text {-Reformulation: "your work... the work you did" }\end{array}$} \\
\hline Self-confidence: 5 & $\begin{array}{l}\text { Execution: CS.2.1/CS2.2/ } \\
\mathrm{CS} 3 / \mathrm{CS} 4\end{array}$ & \\
\hline Creativity: 3 & Repair: --- & \\
\hline ST17. R1 & Communication strategies & Indicators \\
\hline Fluency: 6 & Planning: CS1.2 & \multirow{3}{*}{$\begin{array}{l}\text {-Islands of reliability: personal introduction, formal presentation } \\
\text { signposting, fixed expressions ("day after day", "more and more") } \\
\text {-Fillers: fixed expressions, vocalizations, repetition ("other people can, } \\
\text { can, can understand", "I will be, I will be") } \\
\text {-Reformulation: "me, Carolina Sala" (expressing conviction) } \\
\text {-Foreignizing/trying out: "talking with my friend doing the coffee" } \\
\text {-Over generalizing: "all this kind of things", "that things" }\end{array}$} \\
\hline Self-confidence: 5 & $\begin{array}{l}\text { Execution: CS2.1/CS2.4/ } \\
\text { CS3/CS4 }\end{array}$ & \\
\hline Creativity: 4 & Repair: --- & \\
\hline ST17. R2 & Communication strategies & Indicators \\
\hline Fluency: 6 & Planning: CS1.2 & \multirow{3}{*}{$\begin{array}{l}\text {-Self-correction: "a topic normal... a normal topic", "have the best... } \\
\text { give the best" } \\
\text {-Foreignizing/trying:"a bored task","kings' night","making the } \\
\text { classes" } \\
\text {-Over generalizing: "everybody is saying a lot of different things", } \\
\text { "the best things of you" } \\
\text {-Islands of reliability: fixed expressions ("I would like to say that") }\end{array}$} \\
\hline Self-confidence: 5 & $\begin{array}{l}\text { Execution: CS2.1/CS2.4/ } \\
\text { CS3/CS4 }\end{array}$ & \\
\hline Creativity: 6 & Repair: CS5 & \\
\hline
\end{tabular}




\begin{tabular}{|c|c|c|}
\hline & & -Fillers: vocalizations (“eh..."), fixed expressions, repetition \\
\hline ST18. R1 & Communication strategies & Indicators \\
\hline Fluency: 1 & Planning: CS1.2 & \multirow{3}{*}{$\begin{array}{l}\text {-Foreignizing/trying out: "facilities", "all body", "expectatives" } \\
\text {-Trying out: "I am going to see off" (wrong!) } \\
\text {-Islands of reliability: intro., reference to script (course objectives), } \\
\text { fixed expressions ("good bye and good luck")“, pet words ("really") } \\
\text {-Fillers: abundant repetition/vocalizations } \\
\text {-Self-correction: "this will be not easy... this won't be easy" }\end{array}$} \\
\hline Self-confidence: 1 & $\begin{array}{l}\text { Execution: } \\
\text { CS3/CS4 }\end{array}$ & \\
\hline Creativity: 1 & Repair: CS5 & \\
\hline ST18. R2 & Communication strategies & $\begin{array}{ll}\text { Indicators } \\
\end{array}$ \\
\hline Fluency: 3 & Planning: CS1.2 & \multirow{3}{*}{$\begin{array}{l}\text {-Foreignizing/trying out:"put me nervous", "you knows", "demostrate" } \\
\text {-Trying out: "the words begin to be forgiven" (wrong!) } \\
\text {-Islands of reliability: reference to script, pet words ("really good"), } \\
\text { linkers ("in spite of all") } \\
\text {-Fillers: vocalizations, repetition, pet words } \\
\text {-Self-correction: "I will improve... I have to improve" } \\
\text {-Prosodic features: rhythm has improved }\end{array}$} \\
\hline Self-confidence: 3 & $\begin{array}{l}\text { Execution: } \\
\mathrm{CS} 3 / \mathrm{CS} 4\end{array}$ & \\
\hline Creativity: 2 & Repair: CS5 & \\
\hline ST19. R1 & Communication strategies & Indicators \\
\hline Fluency: 3 & Planning: CS1.2 & \multirow{3}{*}{$\begin{array}{l}\text {-Islands of reliability: personal intro., ref. to script (course objectives), } \\
\text { fixed expressions ("I will try to do my best", "that's all"), linkers } \\
\text {-Prosodic features: intonation (in enumerations), rhythm (alternating } \\
\text { pauses/long chunks) } \\
\text {-Over generalizing: "an important thing", "another thing", } \\
\text {-Foreignizing/trying out: "I only can say", "I don’t know how will be } \\
\text { my English" } \\
\text {-Fillers: vocalizations, repetition ("during this term") }\end{array}$} \\
\hline Self-confidence: 2 & $\begin{array}{l}\text { Execution: CS2.1/CS2.4/ } \\
\text { CS3/CS4 }\end{array}$ & \\
\hline Creativity: 3 & Repair: --- & \\
\hline ST19. R2 & Communication strategies & Indicators \\
\hline Fluency: 5 & Planning: CS1.2 & \multirow{3}{*}{$\begin{array}{l}\text {-Islands of reliability: formal presentation signposting ("to conclude, I } \\
\text { want to say") } \\
\text {-Prosodic features: intonation (enumer.), word linking, steady rhythm } \\
\text {-Self-correction: "good friends of mine... good friends of me" (wrong!) } \\
\text {-Fillers: stretched sounds, repetition, vocalizations } \\
\text {-Over generalizing: "different places", "like that" } \\
\text {-Foreignizing/trying out: attractives", "as the time went by", "different } \\
\text { places of Spain" }\end{array}$} \\
\hline Self-confidence: 3 & $\begin{array}{l}\text { Execution: CS2.1/CS2.4/ } \\
\mathrm{CS} 3 / \mathrm{CS} 4\end{array}$ & \\
\hline Creati & Repair: CS5 & \\
\hline ST20. R1 & Communication strategies & Indicators \\
\hline Fluen & Planning: & \multirow{3}{*}{$\begin{array}{l}\text {-Islands of reliability: signposting introduction/ending, pet words } \\
\text { ("well"), fixed expressions ("of course", "I would like to say") } \\
\text {-Fillers: abundant vocalizations/repetition, stretched vowels, pet words } \\
\text {-Self-correction: "a conversation about something... about every } \\
\text { things" (wrong!) } \\
\text {-Reformulation: "the other troncal level... the normal troncal level" } \\
\text {-Modalization: "maybe we have to work hard", "I think that" } \\
\text {-Foreignizing/trying out: "the other objective is pass this subject", "I } \\
\text { will explain you", "I would like to say you" }\end{array}$} \\
\hline Self-confidence: 3 & $\begin{array}{l}\text { Execution: CS2.2/CS2.4/ } \\
\mathrm{CS} 3 / \mathrm{CS} 4\end{array}$ & \\
\hline Creat & Repair: CS5 & \\
\hline ST20. & Communication & \multirow{4}{*}{$\begin{array}{l}\text { Indicators } \\
\text {-Over generalizing: "and all of this", "it's a different thing", "the } \\
\text { others type of classes" } \\
\text {-Modalization: "I think", "maybe I want to start" } \\
\text {-Islands of reliability: introduction, fixed expressions ("first of all", } \\
\text { "oh my God"), pet phrases ("you know") } \\
\text {-Fillers: vocalizations, repetition, pet words, cough (1'26") } \\
\text {-Self-correction: "If you went... if you go" } \\
\text {-Reformulation: "I would like to visit... I would like to knew" (trying } \\
\text { out wrong reformulation!) }\end{array}$} \\
\hline Fluency: 5 & Planning: CS1.2 & \\
\hline Self-confidence: 5 & $\begin{array}{l}\text { Execution: CS2.1/CS2.2/ } \\
\mathrm{CS} 2.4 / \mathrm{CS} 3 / \mathrm{CS} 4\end{array}$ & \\
\hline Creativity: 5 & Repair: CS5 & \\
\hline
\end{tabular}




\begin{tabular}{|c|c|c|}
\hline & & $\begin{array}{l}\text {-Prosodic features: intonation, rhythm (0'36") } \\
\text {-Foreignizing/trying out: "I would like to say you”, “I don't have clear } \\
\text { many things" }\end{array}$ \\
\hline ST21. R1 & Communication strategies & Indicators \\
\hline Fluency: 5 & Planning: CS1.1 (Reads!) & \multirow{3}{*}{$\begin{array}{l}\text {-Islands of reliability: follows a previous script closely } \\
\text {-Prosodic features: characteristic rhythm/intonation of read } \\
\text { monologues (lack of pauses/fillers), neutral tone } \\
\text {-Foreign./trying:"differents than I thought", "before to go they asked } \\
\text { to the agency", "the shape of life", "a person who knows speak } \\
\text { English" } \\
\text {-Over generalizing: "this is a place", "everybody", } \\
\text {-Modalization: "maybe I have to remember", "I think" }\end{array}$} \\
\hline Self-confidence: 3 & $\begin{array}{l}\text { Execution: CS2.1/CS2.4/ } \\
\text { CS3/CS4 }\end{array}$ & \\
\hline Creativity: 1 & Repair: --- & \\
\hline ST21. R2 & on strategies & Indicators \\
\hline Fluency: 5 & Planning: CS1.2 & \multirow{3}{*}{$\begin{array}{l}\text {-Islands of reliability: introduction, pet words ("well") } \\
\text {-Foreign./trying:“for you can understand", "we are a little bit stupids" } \\
\text {-Over generalizing: "an important place", "other things" } \\
\text {-Self-correction: "her faces... their faces", "this is... was important in } \\
\text { the city" } \\
\text {-Reformulation: "Barcelona has... offers", } \\
\text {-Fillers: pet words, repetition } \\
\text {-Modalization: "I think", "I don’t like so much" }\end{array}$} \\
\hline Self-confidence: 3 & $\begin{array}{l}\text { Execution: CS2.1/CS2.2/ } \\
\mathrm{CS} 2.4 / \mathrm{CS} 3 / \mathrm{CS} 4\end{array}$ & \\
\hline Creativity: 3 & Repair: CS5 & \\
\hline ST22. R1 & Communication strategies & Indicators \\
\hline Fluency: 6 & Planning: CS1.2 & \multirow{3}{*}{$\begin{array}{l}\text {-Islands of reliability: personal introduction, formal presentation } \\
\text { signposting, explicit reference to script } \\
\text {-Prosodic features: intonation, rhythm (1'00"), stress (2'12", 2'30") } \\
\text {-Foreignizing/trying out: "orals exams", "how can I expect, no?" "I } \\
\text { would like that in this course I have a good level", "realist" } \\
\text {-Fillers: vocalizations, stretched vowels, scarce repetition, fixed expr. }\end{array}$} \\
\hline Self-confidence: 5 & $\begin{array}{l}\text { Execution: } \\
\text { CS3/CS4 }\end{array}$ & \\
\hline Creativity: 2 & Repair: --- & \\
\hline ST22. R2 & Communication strategies & \\
\hline Fluency: 6 & Planning: CS1.2 & \multirow{3}{*}{$\begin{array}{l}\text {-Islands of reliability: reference to script, fixed expressions ("I don’t } \\
\text { know", "of course") } \\
\text {-Fillers: vocalizations, repetition, stretched vowels, fixed expressions } \\
\text {-Prosodic features: intonation (2'29"), rhythm (2'56"), stress (0'55") } \\
\text {-Over generalizing: "it's an important thing", "all these things" } \\
\text {-Foreignizing/trying out: "career", "I explain you in the last orals" } \\
\text {-Reformulation: "I would like when I finish... I would like to go" } \\
\text {-Self-correction: "we need to do... to did a presentation" (wrong!) } \\
\text {-Use of L1: "restauració", "allotjament" }\end{array}$} \\
\hline Self-confidence: 5 & $\begin{array}{l}\text { Execution: CS2.1/CS2.2/ } \\
\mathrm{CS} 2.4 / \mathrm{CS} 3 / \mathrm{CS} 4\end{array}$ & \\
\hline Creativity: 4 & Repair: CS5 & \\
\hline ST23. R1 & Communication strategies & Indicators \\
\hline Fluency: 4 & Planning: CS1.2 & \multirow{3}{*}{$\begin{array}{l}\text {-Islands of reliability: personal introduction, exemplification } \\
\text {-Fillers: cough, enumeration (countries), repetition, vocalizations } \\
\text {-Over generalizing: "this type of things", "a very different type of" } \\
\text {-Foreignizing/trying out: "has a very symbolist", "I ocupe a position of } \\
\text { secretary" } \\
\text {-Use of L1 } \\
\text {-Self-correction: "a dog call... and is called Roc" }\end{array}$} \\
\hline Self-confidence: 2 & $\begin{array}{l}\text { Execution: CS2.1/CS2.4/ } \\
\text { CS3/CS4 }\end{array}$ & \\
\hline Creativity: 1 & Repair: CS5 & \\
\hline ST23. R2 & Communication strategies & Indicators \\
\hline Fluency: 4 & Planning: CS1.1 & $\begin{array}{l}\text {-Islands of reliability: personal introduction, linkers } \\
\text {-Over generalizing: "other things" } \\
\text {-Foreignizing/trying out: "the last week" } \\
\text {-Fillers: vocalizations, scarce fixed expressions }\end{array}$ \\
\hline
\end{tabular}




\section{REFERENCES}

[1]. Council for Cultural Co-operation. Common European Framework of Reference for Languages: Learning, Teaching, Assessment, Cambridge University Press, Cambridge, 2001. Online available from http://www.coe.int/t/dg4/linguistic/Source/Framework_EN.p df

[2]. Z. Dörnyei, M.L. Scott. Review article. Communication strategies in second language: Definitions and taxonomies, Language Learning, Vol.47, 173-210.

[3]. M. Canale. From Communicative Competence to Communicative Language Pedagogy, in J.C. Richards, R. Schmidt (eds.), English for Cross-Cultural Communication, Longman, New York, 1983.

[4]. M.H. Long. Native speaker/non-native speaker conversation and the negotiation of comprehensible input, Applied Linguistics, Vol.4, 126-141.

[5]. Z. Dörnyei. On the teachability of communication strategies, TESOL Quarterly, Vol.29, No.1, 55-85.

[6]. Y. Nakatani, Developing an oral communication strategy inventory, Modern Language Journal, Vol.90, 152-167.

[7]. L. Selinker. Interlanguage, International Review of Applied Linguistics, Vol.10, 209-230.

[8]. S. Savignon. Communicative Competence: An Experiment in Foreign Language Teaching, Centre for Curriculum Development, Philadelphia, 1972.

[9]. T. Varadi. Strategies of target language learner communication: Message adjustment, International Review of Applied Linguistics, Vol.18, No.1, 59-71.

[10]. E. Tarone. Conscious communication strategies in interlanguage: A progress report, TESOL, Vol.77, 194-203.

[11]. E. Tarone. Communication strategies, foreigner talk and repair in interlanguage, Language Learning, Vol.30, 417-431.

[12]. E. Bialystok. Some Factors in the Selection and Implementation of Communication Strategies, in C. Faerch, G. Kasper (eds.), Strategies in Interlanguage Communication, Longman, London, 1983.

[13]. E. Bialystok. Strategies in Interlanguage Learning and Performance, in A.C. Davies, C. Criper, A.P.R. Howatt (eds.), Interlanguage, Edinburgh University Press, Edinburgh, 1984.

[14]. E. Bialystok. Communication Strategies: A Psychological Analysis of Second Language Use, Blackwell, Oxford, 1990.

[15]. M. Canale, M. Swain. Theoretical basis of communicative approaches to second language teaching and testing, Applied Linguistics, Vol.1, No.1, 1-47, 1980.

[16]. S.P. Corder.. Error Analysis and Interlanguage, Oxford University Press, Oxford, 1981.

[17]. C. Færch, G. Kasper (eds.). Strategies in Interlanguage Communication, Longman, London, 1983.
[18]. Z. Dörnyei, A.D. Cohen. Focus on the Language Learner: Motivation, Styles, and Strategies, in N. Schmitt (ed.), An Introduction to Applied Linguistics, Arnold, London, 2002.

[19]. Y. Nakatani. The effects of awareness-raising training on oral communication strategy use, The Modern Language Journal, Vol.89, 76-91.

[20]. S.M. Gass, E.M. Varonis. Incorporated Repairs in Non-native Discourse, in M. Eisemstein (ed.), The Dynamic Interlanguage: Variation in Second Language Acquisition, Plenum Press, New York, 1990.

[21]. M. Rost, S. Ross. Learner use of strategies in interaction: Typology and teachability, Language Learning, Vol.41, No.2, 235-273.

[22]. J. Williams, R. Inscoe, T. Tasker. Communication Strategies in an Interactional Context: The Mutual Achievement of Comprehension, in G. Kasper, E. Kellerman (eds.), Communication Strategies, Longman, Essex, 1997.

[23]. N. Poulisse. The Use of Compensatory Strategies by Dutch Learners of English, Foris, Dordrecht, 1990.

[24]. G. Yule, E. Tarone. The Other Side of the Page: Integrating the Study of Communication Strategies and Negotiated Input in SLA, in R. Phillipson, E. Kellerman, L. Selinker, M. Sharwood-Smith, M. Swain (eds.), Foreign and Second Language Pedagogy Research: A Commemorative Volume for Claus Færch, Multilingual Matters, Clevedon, 1991.

[25]. R. Schmidt. Deconstructing consciousness in search of useful definitions for applied linguistics, AILA Review, Vol.11, 11-26.

[26]. T. Paribakht. On the pedagogical relevance of strategic competence, TESL Canada Journal, Vol.3, 53-66.

[27]. S.P. Corder. Strategies of Communication, in In Strategies in Interlanguage Communication, in C. Faerch, G. Kasper (eds.), Strategies in Interlanguage Communication, Longman, London, 1983.

[28]. T. Bongaerts, N. Poulisse. Communication strategies in L1 and L2: Same or different?, Applied Linguistics, Vol.10, 253-267.

[29]. F.B. Brooks. Can we talk?, Foreign Language Annals, Vol.25, 59-71.

[30]. G.M. Willems. Communication strategies and their significance in Foreign Language Teaching, System, Vol.15, 351-364.

[31]. W. Lam. Gauging the effects of ESL oral communication strategy teaching: A multi-method approach, Electronic Journal of Foreign Language Teaching, Vol.3, 142-157.

[32]. W. Lam, J. Wong. The affects of strategy training on developing discussion skills in an ESL classroom, ELT Journal, Vol.54, No.3, 245-255.

[33]. R. Ellis. Second Language Acquisition. Oxford Introductions to Language Study, Oxford University Press, Oxford, New York, 1997.

[34]. H. Calsamiglia, A. Tusón. Las cosas del decir, Ariel, Barcelona, 1999

[35]. S. Luoma. Assessing Speaking, Cambridge University Press, Cambridge, 2004. 
[36]. F.J. Cantero. Conceptos clave en lengua oral, in A. Mendoza (coord.), Conceptos clave en didáctica de la lengua y la literatura, Horsori, Barcelona, 1998.

[37]. J. House. Developing pragmatic fluency in English as a foreign language: Routines and metapragmatic awareness, Studies in Second Language Acquisition, Vol.8, No.2, 225-252, 1996.

[38]. J. Kenworthy. Teaching English Pronunciation, Longman, London, 1987

[39]. J.S. Delett, S. Barnhardt, J.A. Kevorkian. A framework for portfolio assessment in the foreign language classroom, Foreign Language Annals, Vol.34, No.6, 559-568, 2001.

[40]. M.T. Colén, N. Giné, F. Imbernón. La carpeta de aprendizaje del alumnado universitario, Octaedro-ICE, Barcelona, 2006.

[41]. V. Kohonen. The European Language Portfolio: From Portfolio Assessment to Portfolio-Oriented Language Learning, University of Tampere, Tampere, 2007.

[42]. R.J. Tierney, M.A. Carter, L.E. Desai. Portfolio Assessment in the Reading-Writing Classroom, Christopher Gordon Publishers, Norwood, 1991.

[43]. D.M. Frazier, F.L. Paulson. How portfolios motivate reluctant writers, Educational Leadership, Vol.49, No.8, 62-65.
[44]. W.S. Freedman. Linking large-scale testing and classroom portfolio assessments of student writing, Educational Assessment, Vol.1, No.1, 27-52.

[45]. H. Wang, L. Cheng. Portfolio assessment for ESL writing, Contact, Vol.29, No.3, 50-54.

[46]. D.E. Murray. Using portfolios to assess writing, Prospect: A Journal of Australian TESOL, Vol.9, 56-69.

[47]. M. Gearhart, S.A. Wolf. Issues in portfolio assessment: Assessing writing processes from their products, Educational Assessment, Vol.4, 265-296.

[48]. B. Song, B. August. Using portfolios to assess the writing of ESL students: A powerful alternative?, Journal of Second Language Writing, Vol.11, No.1, 49-72.

[49]. A. Hirvela, L. Sweetland. Two case studies of L2 writers' experiences across learning-directed portfolio contexts, Assessing Writing, Vol.10, 192-213.

[50]. L. Hamp-Lyons, W. Condon. Assessing the Portfolio: Principles for Practice, Theory and Research, Hampton Press, New Jersey, 2000.

[51]. S.Y. Ali. An introduction to electronic portfolios in the language classroom', The Internet TESL Journal, Vol.11, No.8, 15-23, 2005. Online available from http://iteslj.org/Techniques/Ali-Portfolios.html 